Volume: 11 Issue: 2 Year: 2014

\section{Child abuse and neglect}

\author{
İlyas Özgentürk ${ }^{1}$
}

\begin{abstract}
Children's physical, emotional and sexual abuse and neglect are widespread social and health problem across societies. Child abuse covers all kinds of attitudes and neglects that affect and limit children physical and emotional development by the parents or child careers. Child abuse affects the children's emotional and physical development negatively. A child whose emotional development is disturbed lives with very serious psychological and communication problems as well as decrease of life quality. Child abuse can be a learned and passed through cognitive behavior. It is known that the perpetrators of child abuse are also victims of child abuse in their own childhoods. Child abuse can be one kind of cycle of violence. Today's victims of child abuse have a tendency to become the perpetrators of tomorrow's child of abuse. Child abuse can be prevented by the collective efforts of the whole community. Establishing a collective consciousness about the harms of the child abuse can become the initial step of fighting against child abuse. The considerable success can be reached when effective public policies, which attribute to collective consciousness addressing different fractions of the society are established.
\end{abstract}

Keywords: child abuse, violence against child, child neglect, psychological abuse, physical abuse

(Extended English abstract is at the end of this document)

\footnotetext{
${ }^{1}$ Dr., Polis Akademisi, Elmadag PMYO, iozgenturk@egm.gov.tr
}

Çocukların fiziksel, duygusal ve cinsel yönden istismar ve ihmal edilmesi tüm toplumlarda yaygin görülen bir sosyal ve sağlik sorunudur. Çocuk istismarı ve ihmali; çocuğun anne, babası ya da bakmakla yükümlü olan bir kimse tarafindan çocuğun fiziksel ve duygusal gelişimini engelleyen ya da kısıtlayan eylem ve ihmallerin tümüdür Çocuk istismarı çocuğun duygusal ve fiziksel gelişimini olumsuz yönde etkiler. Duygusal gelişimleri bozulan çocukların yaşam kaliteleri düşer ve sonraki yaşamlarında ciddi psikolojik ve iletişim sorunları yaşarlar. Çocuk istismarı öğrenilen ve nesilden nesile aktarılan bir davranıştır. Çocuklarını istismar eden kissilerin bir zamanlar kendilerinin de çocukluklarında istismara maruz kaldıkları bilinmektedir. Çocuk istismarı bir çeşit şiddet döngüsü halini gelebilmektedir. Bugünün çocuk istismarı mağdurlarının yarının çocuk istismarc1lar1 olma ihtimali yüksektir. Çocuk istismar1 ancak tüm toplumun ortak mücadelesi ile engellenebilir. Çocuk istismarının zararları konusunda toplumda bilinçsel bir duyarll11k oluşturulması mücadelenin birinci basamağıdır. $\mathrm{Bu}$ bilinç toplumun tüm kesimlerini kapsayıc1 etkili kamu politikalarıla desteklendiğinde gerçek başarı elde edilebilir.

Anahtar Kelimeler: çocuk istismarı, çocuğa karş1 şiddet, çocuğun ihmali, psikolojik şiddet, fiziksel şiddet 


\section{Giriş}

Çocuk istismarı, çocuğa karşı şiddet ve ihmal tüm toplumlarda yaygin olarak görülen bir sosyal ve sağlık sorundur. Çocuk istismarı tüm dünyada her yıl milyonlarca insanı olumsuz olarak etkilemektedir. Çocuğa karşı yapılan tüm kötü muamele türleri uzun yıllardan beri sosyal bilimcilerin, araştırmacıların ve resmi otoritelerin dikkatini çekmekte ve üzerinde çok çeşitli araştırmalar yapılmaktadır (Zeren ve ark.; 2012:536; Schwartz ve McCauley, 2007:123).

Dünya Sağlık Örgütüne göre; çocuğa karşı kötü muamele daha genel ve kapsayıcı bir ifade olmakla beraber, çocuk istismarı ve ihmali daha özel ve teknik tanımlamalar olarak nitelendirilmektedir. Çocuğa karşı kötü muamele; çocuğun sağlı̆̆ına, gelişimine ve onuruna karşı gerçek veya potansiyel tehlike oluşturan her türlü fiziksel, duygusal ve cinsel şiddet, ihmal ve çocuğun sömürülmesi için yapılan davranıştır. Bu geniş tanımlama içinde çocuğa karşı kötü muamele; fiziksel, cinsel ve duygusal şiddet, ihmal ve sömürme şeklinde beş ayrı alt başlıkta değerlendirilebilir (WHO, 2014). Çocuk istismarı ve ihmali; çocuğun anne, babası ya da bakmakla yükümlü olan bir kimse tarafindan çocuğun fiziksel ve duygusal gelişimini engelleyen ya da kısıtlayan eylem ve ihmallerin tümüdür. Howe'e (2005:90) göre; çocukların istismar ve ihmal edilmesi çocukların çeşitli şekillerde zarar görmesine veya hastalanmasına neden olan her çeşit fiziksel, duygusal, cinsel şiddet ve ihmal içeren davranışları kapsar.

Dünya Sağlık Örgütü tarafından yapılan bir araştırmada, yaklaşık olarak araştırmaya katılan kadınların yüzde yirmisi ve erkeklerin yüzde beşi çocukken cinsel istismara, çocukların ise yüzde yirmi beşi ile ellisi arasında bir rakamın fiziksel şiddete maruz kaldığını rapor etmişlerdir.

Çocuklarda yaşam boyu olumsuz etkiler bırakan kötü muamelenin çocukların fiziksel, duygusal gelişimini olumsuz etkilediği, okul başarısını düşürdüğü, iş ve aile yaşamında iletişim sorunlarına neden olduğu görülmüştür. Sonuç olarak, çocuklara karşı kötü muamele tüm insanlığın yaşam kalitesini düşüren, ekonomik ve sosyal gelişmesini olumsuz olarak etkileyen yaygın bir sorundur (WHO, 2014).

\section{Çocuğa Karşı İstismar Türleri}

Dünya Sağlık Örgütüne göre çocuğa karşı kötü muamele fiziksel, cinsel ve duygusal istismar, ihmal ve sömürme olarak beş ayrı alt başlıkta değerlendirilebilir (WHO, 2014). İhmal çocuğa karşı kötü muamele sayılan davranışlardan en genel olanıdır. İhmalden sonra sırası ile fiziksel şiddet, psikolojik şiddet ve cinsel şiddet suçları gelmektedir. Zoroglu ve ark. (2001:69) tarafından yapılan bir araştırmada ihmalin (\%16.5) en sık bildirilen ruhsal travma olduğunu, bunu sıklık açısından duygusal (\%15.9), fiziksel (\%13.5), cinsel (\%10.7) istismarın takip ettiğini tespit edilmişlerdir. 
Özgentürk, İ. (2014). Çocuk istisman1 ve ihmal. International Journal of Human Sciences, 11(2), 265-278. doi: $\underline{10.14687 / \text { ijhs.v11i1.2943 }}$

Çocuklara Karşı Şiddet Amerikan Profesyonel Derneği tarafindan hazırlanan Çocuklara ve Gençlere Psikolojik Kötü muamele Şüphelilerinin Değerlendirilmesi Rehberinde psikolojik kötü muamelenin altı alt çeşidi olduğu tanımlanmıştır (ASPAC, 1995).

a) Yok sayma; çocuğu düşmanca bir şekilde reddetme ve çocuğu değersizleştirme,

b) Korkutma; ebeveyn tarafindan çocuğun devamlı surette bir şey istediği taktirde terk etmekle, zarar vermekle ve öldürmekle tehdit edilmesi,

c) Soyutlama; çocuğun günlük aktivitelerden ve diğer çocuklardan soyutlaması,

d) Suça teşvik etme; ebeveyn görevinin kötüye kullanılarak çocuğun suça veya suç sayılan faaliyetlere teşvik edilmesi,

e) Duyarsızlık; çocuğun duygusal ihtiyaçlarına karşı duyarsız kalınması,

f) Tedavi İhtiyaçlarını İhmal; çocuğun her türlü sağlık ve tedavi ihtiyacının ihmal edilmesi.

\section{Fiziksel İstismar}

En s1k rastlanan ve belirlenmesi en kolay şiddet türüdür. Howe’e (2005:69) göre fiziksel şiddet çocuğa fiziksel olarak zarar verebilecek olan her türlü yumruk, tokat, tekme, sarsma, yakma, boğma, ısırma ve zehirleme gibi davranışları ifade etmektedir. Fiziksel şiddet çocukların hem bedensel hem de psikolojik bütünlüğüne karşı yapılan bir saldırıdır. Çocuğa ebeveynleri ya da bakmakla sorumlu olan kişilerce yapılan kötü muamele nedeniyle yaralanmasını kapsar. En sık dövme seklinde görülür (Kara ve ark., 2004:148). Rapp-Paglicci ve Loeber (2007:124) fiziksel şiddeti bilinçli ve isteyerek yapılan ve çocuklara fiziksel olarak zarar verecek her türlü davranış olarak tanımlamaktadırlar. Özet olarak; ebeveynler tarafından çocuklara karşı fiziksel şiddet uygulanması çok geniş kapsamlı ve sonuçları ağır olan, saldırganca, çocukları kontrol etmeyi ve cezalandırmayı kapsayan her türlü davranıştır.

Bazı ebeveynler şiddeti çocukları disipline etmek için başvurabilecek bir yöntem olarak görmektedirler. Ebeveynler kontrol edemedikleri yaramaz ve söz dinlemeyen çocuklarını istedikleri noktaya getirebilmek için şiddet içeren davranışlara başvurmaktadır. Ebeveynler bu acımasız tekniklere sadece çocuklarını disiplin altına alabilmek için başvurduklarını ileri sürerek kendilerini savunurlar. Çocukları disiplin altında tutmak ve kontrol edebilmek için kullanılan ve çocuklara fazla zarar vermeyen bu tekniklerin bazıları kabul edilebilir olsa da, bazıları gerçekten çocuklar için çok ağır fiziki ve psikolojik sonuçlar doğurmakta ve çocuklar için ciddi endişe verici bir tehdit oluşturmaktadır. Pek çok toplum kültürel olarak ebeveynler tarafindan çocukları disipline etmek için kullanılan bu cezalandırıcı tekniklere karşı kısmen ya da tamamen tolerans göstermektedir. $\mathrm{Bu}$ tolerans da şiddetin meşru hale gelmesini sağlamaktadır (Güneş, 2012:107; Howe, 2005:68). 
Özgentürk, İ. (2014). Çocuk istisman1 ve ihmal. International Journal of Human Sciences, 11(2), 265-278. doi: $\underline{10.14687 / \text { ijhs.v11i1.2943 }}$

Türkiye'de Çocuk İstismarı ile ilgili yapılan bir araştırma sonucuna göre; 7-14 yaş dilimindeki kız çocukları en çok anne, baba, öğretmen, arkadaş ve büyük kardeşler tarafindan fiziksel şiddete maruz kaldıklarını, erkek çocuklar ise sırasıyla, arkadaş, öğretmen, baba, büyük kardeş ve tanımadıkları birinin fiziksel şiddetine maruz kaldıklarını rapor etmişlerdir. 15-18 yaş diliminde, az sayıda kız fiziksel istismar bildirmişlerdir. Kızlar fiziksel şiddet uygulayanların daha çok babaları ve öğretmenleri olduğunu söylemişlerdir. 15-18 yaş dilimindeki erkekler daha çok baba, arkadaş ve tanımadıkları kişiler tarafından fiziksel şiddete uğradıklarını belirtmişlerdir. Bütün yaş gruplarında en çok annelerin kullandığ1 fiziksel istismar yöntemi olarak "terlik atma” rapor edilmiştir (Türkiye’de Çocuk İstismarı ve Aile İçi Şiddet Araştırması, 2010:22)

Knutson (1995: 412)'a göre çocuk ölümlerinde kötü muamele sonucu meydana gelen ölümlerin yarıya yakını fiziksel şiddet sonucunda meydana gelmektedir. Şiddet mağduru çocukların ölümü bazen kontrolünü kaybetmiş olan bir yetiştinin aşırı şiddet içeren ani bir davranışının sonucu olabileceği gibi bazen de sistemli olarak uygulanan şiddetin ve dayağın birikiminin bir sonucu olabilmektedir. Beş yaşının altındaki çocuklar fiziksel şiddet sonucu ölümlerde en fazla risk oranı taşıyan gurup olmakla birlikte on iki aydan daha düşük yaştaki bebeklerin de şiddet sonucu öldükleri hatta bu yaş gurubu için şiddet sonucu ölümlerin tüm yaş grupları içinde üçüncü sırada geldiği tespit edilmiştir.

Özellikle özürlü ve engelli çocuklar bakımlarının zor olması nedeniyle aileleri ve bakıcıları için ciddi bir üzüntü ve stres kaynağıdırlar. Fiziksel olarak engelli, öğrenme, görme ve işitme güçlüğü olan çocukların şiddet mağduru olma ihtimali daha fazladır. Buna paralel olarak, psikolojik olarak rahatsız ebeveynlere veya bakıcılara sahip olan çocukların da stresli ve gergin ortamlarda fiziksel şiddet mağduru olma ihtimali yüksektir (Knutson, 1995: 412).

Çocuklar aynı anda birden fazla şiddet türüne maruz kalabilmektedirler. Claussenn ve Crittenden (1991) tarafindan gerçekleştirilen bir çalışmada fiziksel şiddet mağduru çocukların aynı zamanda psikolojik şiddete de maruz kaldıkları tespit edilmiştir. Fiziksel şiddete uğrayan çocuklar duygu yoğunlukları az olduğu, iletişim kurmada zorluklar yaşadıkları ve duygularını öfke içeren davranışlar ile gösterdikleri için duygusal şiddetten daha fazla etkilenmektedirler (Tıraşçı ve Gören, 2007:71).

\section{Duygusal İstismar}

Duygusal şiddet ve ihmal oldukça sık görülmekle birlikte, yasal olarak tanımlanması, fark edilmesi, ve rapor edilmesi en zor olan istismar türüdür. Duygusal şiddet, çocukların gereksinim duydukları yakınlık, ilgi, sevgi ve bakımdan mahrum bırakılarak duygusal gelişimlerinin engellenmesidir (Taner ve Gökler, 2004). Psikolojik kötü muamele; psikolojik şiddet, ihmal ve 
Özgentürk, İ. (2014). Çocuk istisman1 ve ihmal. International Journal of Human Sciences, 11(2), 265-278. doi: $\underline{10.14687 / \text { ijhs.v11i1.2943 }}$

reddetme gibi bir çok kavramı kapsayan daha genel bir tanımlamadır (Howe, 2005:91). RappPaglicci ve Loeber'e (2007:124) göre psikolojik kötü muamele ebeveynler veya çocuklara bakmakla yükümlü olanların çocukların kendilerini değersiz, sevgisiz, istenmeyen bir kişi olarak hissetmesini sağlayan ve onların psikolojik ve biyolojik sağlıklarını tehlikeye atan her türlü davranışıdır. Hart, Brassard ve Karlson (1996:73) psikolojik kötü muameleyi çocukların psikolojik gelişimi için ihtiyaç duyulan gereksinimlerinin zamanında ve yeterince karşılanmaması olarak görmektedir. Psikolojik kötü muamele; Maslow'un ihtiyaçlar sıralamasında bahsettiği, fizyolojik ihtiyaçlar, güvenlik ihtiyaçları, sevgi ve ait olma ve kendine güvenme ihtiyaçlarının karşılanmamasıdır.

En sık söz edilen duygusal istismar yöntemleri; hakaret etmek, alay etmek, lakap takmak, tehdit etmek, bağırmak, fikrini sormamak, baskı yapmak, küçük düşürmek, suçlamak, başkalarıyla k1yaslamak şeklindedir (Türkiye'de Çocuk İstismarı, 2010:18). Türkiye'de Çocuk İstismarı araştırması sonuçlarına göre, çocuklar annelerinden ve babalarından en çok duygusal şiddet, sonra fiziksel şiddet ve ihmal davranışlarını gördüklerini belirtmişlerdir. Annelerin paylaştıkları yaşanmış olaylara göre, duygusal ve fiziksel istismarı, babalardan daha çok annelerin uyguladıkları görülmektedir (Türkiye'de Çocuk İstismarı, 2010:21).

Çocuklara karşı kötü muamele sayılan fiziksel, cinsel, duygusal şiddet ve ihmalin içinde çocuklarda en uzun süre kalıcı etki bırakanı duygusal şiddettir.. Çocuklar kendilerine bakmakla yükümlü olan ebeveynlerine ve bakıcılarına bir tür bağla bağlanmak isterler. Her hangi bir şeye ihtiyaçları olduğunda önce bu kişilerden yardım beklerler. Ancak, çocuklar ihtiyaç duydukları her hangi bir şey için yakınlık ilişkisi içinde oldukları kişilerden bir talepte bulunduklarında onların ilgisizliği ve kayıtsızlığı bazen de şiddet ile karşılık vermesi çocukları psikolojik olara yıkıma uğratır. Ebeveynleri tarafindan sevilmemek, ihmal ve reddedilmek çocuklara çok büyük acı verir Ebeveynleri tarafından reddedilen ve ihmal edilen çocukların gelişimleri daha yavaş ve kendine karşı Öz güvenleri daha az olur. (Iwaniac, 2005:24).

\section{Cinsel İstismar}

Çocuk istismarı türleri içerisinde saptanması en zor olan istismar türüdür. Cinsel istismar, psiko-sosyal gelişimini tamamlamamış ve yaşı küçük olan bir çocuğun bir erişkin tarafindan cinsel doyum için kullanılmasıdır (Kara ve ark.,2004:145). Çocuğun bir yetişkin tarafindan; cinsel uyarı ve doyum için kullanılması, fuhşa zorlanması, pornografi gibi suçlarda cinsel obje olarak kullanılması cinsel istismardır. Cinsel istismarın mutlaka şiddet içermesi gerekmez, çocuğun rızasının olup olmadığına bakılmaz (Polat, 2000:211).

Yaş veya içinde bulunduğu durum itibariyle mağdur çocuk, genellikle kendisine yöneltilen davranışın cinsel içerikli olduğunu dahi algılayabilecek durumda olmadığından on sekiz yaşından 
Özgentürk, İ. (2014). Çocuk istisman1 ve ihmal. International Journal of Human Sciences, 11(2), 265-278. doi: $\underline{10.14687 / \text { ijhs.v11i1.2943 }}$

küçükler için "cinsel istismar” ifadesini kullanılmaktadır. Türk Ceza Kanunu 103. maddesi çocukların cinsel yönden istismarı suçundan bahsetmektedir (Horozgil, 2011:5).

Cinsel istismar toplumda sık rastlanan bir durum olmasına karsın, genellikle duyulan utanç nedeniyle üstü örtülmekte, rapor edilmemekte ve gizli kalmaktadır. Cinsel istismarın en çok yüzde 510 'u ortaya çıkmaktadır. Cinsel istismara ugramış çocukların yüzde 90'ı, tanıdıkları kişiler tarafından istismara maruz kalmaktadır. Yapılan araştırmalar cinsel tacizin en çok üç-beş yaslar arasında görüldügünü ortaya koymaktadır (Turhan ve ark., 2006: 155).

Cinsel istismar çocukların tüm yaşamını etkileye bilir ve uzun süreli duygusal ve davranışsal bozukluklara, korku, depresyon, kızgınlık, düşmanlık ve uygunsuz cinsel davranışlara yol açabilir. Çocuklar kendine yöneltilen cinsel istismarı tam olarak anlayamayacağı için çocukların tedavisinde profesyonel kişilerden destek alınmalıdır (Ovayolu ve ark. 2007:13).

\section{Çocukların İhmali}

İstismar ile ihmal birbirinden farklı şeylerdir. İstismar aktif bir davranış olmakla beraber ihmal pasif bir davranıştır (Kara ve ark.,2004:145). İhmal çocuklara kötü muamelenin en çok dikkatlerden kaçan biçimidir. İhmal çocukların temel fiziksel, duygusal ve eğitim ihtiyaçlarının zamanında ve yeterince karşılanmamasıdır. İhmal edilen çocuklara ebeveynleri tarafindan yeterli ilgi gösterilmediği için bu çocukların fiziksel ve duygusal olarak gelişimi olumsuz yönde etkilenir (RappPaglicci and Loeber, 2007:124).

Genel olarak ihmal çocukların fiziksel, duygusal, bilişsel, eğitim, sosyal ve kültürel ihtiyaçlarının karşılanmasında başarısız olma şeklinde tanımlanabilir. İhmalin; duygusal ihmal, fiziksel ihmal, tıbbi ihmal ve ekonomik ihmal gibi çeşitleri vardır. Fiziksel ihmal çocukların temel fiziksel ihtiyacı olan yemek, uygun barınma ve kıyafet ihtiyaçlarının karşılanmamasıdır. Duygusal ihmal çocuğun psikolojik ve duygusal olarak tanınma ihtiyacına olumsuz cevap verilmesidir (Erickson ve Egeland, 2002). Uzmanlara göre çocukların genel olarak ihmal edilmesi; yeterli olarak beslenmemesi, pis ve sağlıksız ortamlarda yaşatılması, sağlıksız besinlerle beslenmesi, temiz ve uygun olmayan giysiler giydirilmesi, sağlık ve tedavi ihtiyaçlarının giderilmemesi şeklinde olmaktadır (Howe, 2005:111).

\section{İstismarın Temel Nedenleri ve Risk Faktörler}

Çocukların istismarı türüne bağlı olarak çok değişik nedenlerle meydana gelen çok faktörlü karmaşık bir sorundur. Genellikle çocukların fiziksel, zihinsel ve duygusal zayıflıkları nedenleriyle yaşamlarını devam ettirebilmek için yetişkinlere olan bağlılıklarından kaynaklanan nedenlerle meydana geldiğine inanılır. Yapılan araştırmalara göre çocuklar en çok kendilerine bakmakla 
Özgentürk, İ. (2014). Çocuk istisman1 ve ihmal. International Journal of Human Sciences, 11(2), 265-278. doi: $\underline{10.14687 / \text { ijhs.v11i1.2943 }}$

yükümlü olan kişiler ve yakın çevresindeki kişilerce istismar edilmektedir. İstismarın türüne göre bazen çocuk evde sokaktakinden daha fazla risk altındadır. Örneğin, çocuklar evde anne ve babaları tarafindan fiziksel ve duygusal istismara daha fazla maruz kalmaktadır. Bu açıdan güvenli bir yuva olması gereken evler çocuklar için sokaklardan daha tehlikelidir.

\section{İstismarın Nedenleri}

Türkiye'de Çocuk İstismarı ile ilgili olarak 2010 yılında yapılan araştırmada yetişkinler çocuğun yaramazlık yapması, yaramazlık yapmaya devam etmesi, hatalı davranması, söz dinlememesi, yetişkinin istediği gibi davranmaması, 1srar etmesi, bir şey saklaması, ders çalışmaması, izin almadan bir davranışta bulunması, istismarın nedenleri olarak tanımlamaktadır. Ayrıca, yetişkinlere ve çocuklara göre ailelerin ekonomik sıkıntı yaşaması ve ekonomik olarak problemli ailelerde ebeveynlerin sinirli ve saldırgan davranışları istismara yol açan önemli nedenler arasında sayılmıştır (Türkiye'de Çocuk İstismarı, 2010:22).

Düşük gelir seviyesi, dezavantajlı yaşam alanı ve aile yapısı, göç olgusunun varllğı, düşük eğitim düzeyi, zayıf ebeveyn çocuk ilişkisi, ebeveynlerin uyuşturucu ve alkol bağımlılı̆̆ı çocuğa yönelik ihmal ve istismarın ortaya çıkmasında zemin hazırlayıcı etkenler olarak kabul edilmektedir. Ayrıca, toplumsal sorunlar, aile içi sağlıksız iletişim ve etkileşim çocuk istismarını tetikleyen önemli unsurlardır (Kara ve ark., 2004:146).

\section{Çocuk İstismarcılarının Kişiliği ve Mizacı Açısından Nedenler}

Sosyal bilimciler ve psikologlar kişilik oluşumu açısından erken çocukluk döneminin çok önemli olduğunu ifade ederler. Erken çocukluk döneminde çevreden etkilenme çok fazla olduğu için çocukların bu dönemde yaşadıkları tecrübelerin tüm hayatlarını ve davranışlarını etkileyeceğine inanılmaktadır. Çocuk davranışı uzmanları çocukların erken dönemde yaşadıkları olumsuz tecrübelerin daha sonraki yaşamlarında davranış bozukluklarına, zihinsel rahatsızlıklara ve uyumsuzluklara neden olacağına idda etmektedirler (Türkiye'de Çocuk İstismarı ve Aile İçi Şiddet Araştırmas1, 2010:23)

Uzmanlar çocuk istismarcılarının çocukluk dönemlerinde psikolojik sorunlara yol açan olumsuz ve acı verici tecrübeler yaşadıklarını düşünmektedirler. Bu tecrübeler bu kişileri çevrelerine karşı duyarsızlaştırır ve empati yoksunu kişiler haline getirir. Çocuk istismarcıları kendileriyle ve diğer kişilerle bağlılık, duygusal ihtiyaçlarının karşılanması ve kolay incinebilme konularında problemler yaşamaktadırlar. Bu kişiler hafızalarındaki ve şuur altlarındaki bu olumsuz tecrübeleri uzaklaştırmak için yaşamış oldukları kaygılarına savunmacı bir şekilde yaklaşırlar ve kendilerine bakmakla yükümlü olanlarla yaşadıkları problemlerle ilgili olarak ne zaman duygusal sorunlarıyla 
yüzleşseler kendi çocuklarına karşı yakınlık kurma ve bakma ile ilgili tüm sorumluluklarını görmezden gelirler. Bu sorumluluklarını görmezden gelme işlemi kendi çocuklarına veya bakmakla yükümlü oldukları çocuklara karşı kötü muamele, örneğin; çocukların ihtiyaçlarını ihmal etme, ihtiyaçlarına cezalandırma şeklinde cevap verme, çocukları aşağılama, çocukların duygularını ve düşmanca bir şekilde akıllarını kontrol etmeye çalışma, çocukların savunmasız olduklarını göz ardı etme ve ihtiyaç duyduğunda çocuklarla fiziksel olarak bağ kurmayı ihmal etme şeklinde görünür (Güneş, 2014.79/89; Howe, 2005:99).

Çocuklara bakmakla yükümlü olan bu kimseler normal günlük hayatlarında çocuklara karşı olan sorumluluklarını yerine getirme konusunda ellerinden gelenin en iyisini yaparlar. Ancak, çocuklar bakıcılarından daha fazla şeyler talep etmeye başladıklarında bu durum bakıcıları rahatsız eder ve bakıcılarda endişe başlar. Endişe ve stres altında kalan bakıcılarda çocuklara karşı düşmanca tavırlar veya çocukların bu ihtiyaçlarına karşı ihmalkar tutum sergilemeler görülür (Howe, 2005:91).

\section{İstismara Uğrayan Çocukların Genel Tutumları}

Howe (2005)'a göre çocuklar fiziksel ve duygusal olarak zayıf oldukları için yetişkin kişilerin bakımlarına muhtaçtırlar. Çocukların bakımlarını üstlenen kişeler her zaman çocuklar için güven kaynağı değildir. Bazen bu kişiler çocuklar için bir tehlike kaynağıdır. Çocuklar kendilerine kötü muamelede bulunan bu kişilere karşı son derece dikkatlidirler.Çocuklar kendilerine bakmakla yükümlü olan kişiler ile birlikte yaşar iken bu kişilerin kendilerine koruma ve rahat sağlamak yerine tehlike oluşturduğu ve potansiyel tehtidin kaynağı oldukları gerçeğini kısa süre içinde anlar. Ancak, suiistimale uğrayan çocuklar her şeye rağmen içinde bulundukları tehlikeli çevre içinde kendilerine karşı olan bu fiziksel ve psikolojik tehditle başa çıkmak ve sağ kalmak zorundadırlar. İstismar edilen ve duygusal yönden reddedilen çocuklar kendilerine kötü muamelede bulunan bu kişiler ile bu sağlıksız ve düzensiz ilişkilerini devamlı surette yeniden değerlendirir ve bu kişilere karşı bağımlilıklarını en aza indirmeye çalışırlar. Kendilerine kötü muamelede bulunan bakıcılarından dolayı tehlike ile yüzleşen çocuklar bakıcılarının bu olumsuz ve düşmanca davranışlarıyla baş edebilmek için umursamama, itaat etme, duygusal olarak kendini kısıtlama ve saldırganlık gösterme gibi çeşitli stratejiler geliştirirler (Howe, 2005:67).

Sağlıksız ortamlarda yaşamak zorunda olan ve kötü muameleye tabi tutulmuş ve reddedilmiş çocuklar durumlarını daha da kötüleştirmemek için bazı suvunma mekanizmaları geliştirirler. $\mathrm{Bu}$ savunma mekanizmalarından bir tanesi de yaşadıklarını unutmaya çalışmadır. Bu çocuklar yakınlık içeren her türlü bilgiyi unutmaya çalışarak psikolojik olarak acı çekme ve hırpalanmaya karşı kendilerini nasıl savunacaklarını öğrenirler. Kötü muamele edilen ve reddedilen çocuklar başkalarıyla dahi yakın ilişki içinde iken kendilerini yalnız ve endişeli hissederler, kendilerini yalnız ve dışlanmış 

$\underline{10.14687 / \text { ijhs.v11i1.2943 }}$

görürler. Bu öğrenme ne kadar acı çektiğini, başkalarına ihtiyaç duyduğunu, savunmasız olduğunu ve başkalarıyla ilişki kurmaya ne kadar istekli olduğunu hiç kimseye belli etmeme gibi tutum ve davranışları da kapsar. Korku, acı ve üzüntü durumlarında bu çocuklar duymuş oldukları endişeyi dışa vurma konusunda başarısız olmaktadırlar. Ne başkalarından gelecek olan yardım, destek ve bakım ne de koruma konusunda bir arayışları yoktur. Bu kapsamda fiziksel istismarın ve psikolojik kötü muamelenin sonuçlarının beraber ele alınması daha doğru olmaktadır (Howe, 2005:68).

\section{İstismarın ve İhmalin Çocuklar Üzerindeki Etkisi}

Özellikle erken çocukluk dönemindeki (0-6 yaş) çocukların fiziksel olarak oldukça yetersiz olmaları ve çocuk istismarının genellikle evde, kapalı kapılar arkasında meydana gelmesi onun uzun süre yetkili otoriteler tarafindan öğrenilmesini engeller. Ancak, çocuğun ylllarca görmüş olduğu şiddet çocuk üzerinde psikolojik ve davranışsal bazı bozukluklar meydana getirdiği ve davranışsal bozuklukların kritik bir noktaya ulaştığı zaman, okulda öğretmenlerin, mahallede komşuların veya sağlık görevlilerinin dikkatini çeker (Howe, 2005:91).

Çocuk istismarı çocuğa genellikle en yakını olan kişiler tarafından uygulanıyor olması nedeniyle çocuk üzerinde hayatının ilerleyen yıllarını dahi etkileyecek kalıcı travma etkisi yapmaktadır (Yılmaz ve ark., 2003). Her türlü istismar çocukların fiziksel, duygusal ve sosyal gelişimini olumsuz yönde etkiler. Özellikle çocukluk döneminde maruz kalınan her türlü şiddet, istismar ve ihmal çocukta derin izler bırakır, kişinin ileriki yaşlardaki yaşamını olumsuz olarak etkiler ve kişinin akıl ve ruh sağlığını bozar. Araştırmalar, şiddetin öğrenilen bir davranış olduğunu ve erken yaşlarda öğrenildiğini göstermektedir. Şiddeti bir sorun çözme veya cezalandırma aracı olarak kullanılan ailelerde büyüyen çocukların ve gençlerin daha sonra yetişkin oldukları dönemde özellikle kendi eşlerine ya da çocuklarına şiddet uygulama olasıllğ̆ daha yüksektir (Özgentürk ve ark.,2012: 62).

Çocukların duygusal olarak ihmal edilmesi onların her türlü gelişimine önemli ölçüde zarar vermektedir. Çocukların duygusal olarak ihmal edilmesi ve kısıtlanması onların sosyal yaşamda kendini göçlü ve rahat hissetmesini sağlayan duygularının gelişmemesine de neden olur. Aynı zamanda onların fiziksel ve psikolojik sağlıklarını olumsuz olarak etkiler (Howe, 2005:99). Hart ve ark.’a (2002:87) göre ebeveynleri tarafindan reddedilme ve duygusal ihtiyaçlarının karşılanmaması çocuk suçluluğunun en önemli nedenleri arasında yer almaktadır. Psikolojik olarak şiddete uğrayan çocukların korku dolu, endişeli, mutsuz ve stres dolu bir yaşam sürme ihtimalinin diğerlerinden daha fazla olduğu gözlenmektedir.

Duygusal yönden hırpalanmış çocukların okuldaki akademik başarılarının normal gelişimini tamamlayan çocuklarınkinden çok daha düşük olduğu tespit edilmiştir. Bu çocuklar yaşamakta 

$\underline{10.14687 / \text { ijhs.v11i1.2943 }}$

oldukları duygusal gerilimlerden dolayı genellikle anti sosyal davranışlar gösterirler. Bu çocukların davranışları bilinç altında yaşadıkları duygusal gerilimlere karşı tepki içeren reaksiyonlar şeklinde olabilmektedir. Şiddet mağduru çocuklarda aşırı derecede kronik stres nedeniyle gelişim ve fizyolojik sağlık sorunları daha fazla meydana gelebilmektedir. Devamlı surette stres çocukların başta sinir sistemi olmak üzere tüm bağışıklık sistemlerini olumsuz yönde etkileyerek kalıcı hastalıklara neden olabilmektedir (Howe, 2005:99).

\section{Çocukların Şiddete Maruz Kaldıkları Ortamlar}

Sosyoekonomik durumun ve eğitim seviyesinin yetersizliği, kalabalık aileler, aile içi sorunlar ve iletişim eksikliği, anne babanın psikolojik sorunları, aile içi şiddetin varlığı, erozyona uğramış kültürel değerler, örf ve adet, çocuğu koruyan yasa ve kanunların yetersiz olduğu toplumlarda çocuk istismarı daha fazla görülmektedir (Orhon ve ark., 2004). Genel olarak, çocuklarına karşı şiddet uygulayan ebeveynlerin karşılaştıkları sorunlar karşısında gösterdikleri ilk reaksiyon kızgınlık olmaktadır. Çocuklarının kontrol etmek isteyen ancak tam olarak kontrol edemeyen ebeveynler güç ve şiddet kullanarak çocukları üzerindeki otoritelerini yeniden tesis etmeye çalısırlar (Miller-Perrin and Perrin 1999:73).

Çocuklarına karşı fiziksel şiddet kullanan ebeveynlerin pek çoğunun çocukluk döneminin çok zor geçtiği ve sevgisiz ve ilgisiz büyüdükleri tespit edilmiştir Depresyon ve kişilik bozukluğu problemleri olan, uyuşturucu ve alkol bağımlısı ebeveynlerin çocuklarına fiziksel şiddet uygulama ihtimalleri daha yüksektir. Çocuklarına karşı fiziksel şiddet uygulayanlar çocuklarının kendilerine ihtiyacı olduğu düşüncesini reddederler. Çocukları ile yakınlık kurmayı ihmal ederler. Çocuklar tarafindan bakımlarıyla ilgili yapılan talepler nedeniyle ebeveynlerin stres ve endişe seviyesi artar ve nedenle çocukların yakınlık kurmak mesajlarını geri çevirirler (Reder and Duncan, 1999: 64).

Yapılan çalışmalarda eğitim seviyesi ve sosyo-ekonomik statüsü düşük ve yüksek stres altında yaşayan ebeveynlerin fiziksel şiddet uygulamaya daha fazla eğilimli oldukları tespit edilmiştir. Ebeveynleri alkol ve uyuşturucu bağımlısı olan çocukların çocukluk dönemi boyunca fiziksel şiddete uğrama ve ihmal edilme olasılığı oldukça yüksektir. Çocuklarına karşı şiddet kullanan kadınlar üzerine yapılan bir çalışmada çalışmaya katılan kadınların yarıya yakını çocuk iken annesi, diğer yarısı da babası tarafından fiziksel şiddete uyguladığını rapor etmiştir (Howe, 2005:72).

Türkiye'de Çocuk İstismarı araştırmasına göre, yaş, cinsiyet ve bölge farkı olmaksızın araştırmaya katılan bütün çocuklar, istismarın sırasıyla en çok ev, okul ve sokakta gerçekleştiğini, istismar eden kişilerin de sırasıyla baba, öğretmen, anne, arkadaş ve komşu olduğunu anlatmışlardır. Dikkat çekici olarak her yaştan çok sayıda çocuk, okul ortamında öğretmenlerinin fiziksel ve duygusal istismarına uğradıklarını bildirmişlerdir. Yaş itibariyle 7-14 yaş dilimindeki kız çocukları, 
Özgentürk, İ. (2014). Çocuk istisman1 ve ihmal. International Journal of Human Sciences, 11(2), 265-278. doi: $\underline{10.14687 / \text { ijhs.v11i1.2943 }}$

duygusal istismara en çok sırası ile arkadaş, öğretmen, baba ve anneleri tarafindan maruz kaldıklarını, 7-14 yaş aralığındaki erkek çocuklar en çok öğretmenleri, arkadaşları ve babaları tarafından kendilerine duygusal istismar uygulandığının bildirmişlerdir. 15-18 yaş dilimindeki erkekler daha çok arkadaşlarının ve babalarının, aynı yaş dilimindeki kızlar ise öğretmenlerinin ve annelerinin duygusal istismarına uğradıklarını bildirmişlerdir (Türkiye'de Çocuk İstismarı, 2010:22).

\section{Çocukları Her Türlü İstismardan Koruma Yolları}

Çocuk istismarı en çok yakın aile üyeleri, öğretmenler ve akrabalar ve yakın çevreden kişiler tarafından gerçekleştirilmektedir. BM Çocuk Haklarına dair Sözleşme kararları göz önüne alındığında çocukları her türlü istismardan korumak, maruz kaldığı istismarın zararlı etkileri en aza indirmek ve rehabilite etmek için geniş anlamda toplumda bir farkındalık yaratacak eğitim faaliyetlerinin ve kampanyalarının başlatılması gerekmektedir (Türkiye'de Çocuk İstismarı, 2010:24). Çocuk istismarına bağlı ölümlerin \% 61'i önceden engellenebilir bulunmuştur. Korunma önlemleri, şiddetin ortaya çıkısını önlemeye yönelik çalışmalar, erken tanı ve tedavi çalışmaları ve şiddete maruz kalmıs kişinin rehabilitasyonu çabaları olmak üzere üç kategoriye ayrılmaktadır (Turhan ve ark., 2002:156).

Sivil toplum kuruluşlarının ve resmi kurumların başlatacağı faaliyetlerle toplumda bir farkındalık yaratıldıktan sonra, evde ailelerin, okulda öğretmenlerin ve çocukların davranışlarını düzeltmek amacıyla gerekli çalışmalar yapılmalıdır. Şiddet mağdurları kadar şiddet uygulayanların rehabilitasyonu da çok önemlidir. Fiziksel ve aşağılayıcı ceza anlayışının toplumun tüm kesimlerince kabul edilemez olduğuna dair kararlı mesaj vermelidir (Türkiye'de Çocuk İstismarı, 2010:24). Türkiye'de Çocuk İstismarı Özel raporunda göre yetişkinler istismarların önlenebilmesi için yasal otoritelerin alacağı tedbirlerin önemli olduğunu belirtmişlerdir. Tüm kamu kurumları ve otoritelerince çocuk istismarına karşı etkili kamu politikaları geliştirilmelidir. Bu kamu politikaları istismar olayları olmadan önleyici tedbirler, mağdurların tedavisi ve rehabilitasyonu ve şiddet uygulayanların en ağır şekilde cezalandırılmasını sağlayıcı amaçlı olmalıdır. (Türkiye’de Çocuk İstismar1, 2010:24).

Aile içi doğru iletişimin sağlanabilmesi için toplum özellikle eğitim kurumlarınca bilgilendirilmelidir. Çocukların ebeveynler tarafindan daha fazla ilgi ve şefkat gösterilmesi, zaman ayrılması ve dinlenmesi, katı disiplin uygulamalarından vazgeçilmesi anlayışının tüm topluma kazandırılması gerekmektedir (Türkiye'de Çocuk İstismarı, 2010:26). Maddi imkanları iyi olmayan ailelere maddi yardım yapılması da kötü muameleyi önlemede önemli olduğunu vurgulamışlardır (Türkiye'de Çocuk İstismarı, 2010: 29). Ayrıca; çocukları istismardan korumak çeşitli alanlarda birçok temel disiplinleri bir arada kapsayacak araştırmalar yapılmalı ve projeler geliştirilmelidir. 
Özgentürk, İ. (2014). Çocuk istisman1 ve ihmal. International Journal of Human Sciences, 11(2), 265-278. doi: $\underline{10.14687 / \text { ijhs.v11i1.2943 }}$

\section{Sonuç}

Yukarıdaki bilgiler yeniden değerlendirildiğinde çocuk ististamarı ve onun çeşitleri olan fiziksel, duygusal, cinsel şiddet ve ihmal davranışlarının çocuğun fiziksel ve duygusal gelişimi ile onuruna karşı işlenmiş suçlar olduğu görülmektedir. İnsanların erken yaşlarda maruz kaldıkları tüm davranışlar onların sonraki yaşamlarını, fiziksel ve duygusal gelişmelerini etkilemektedir. Çocuk istismarı çok yaygın olmasına rağmen çocukları istismardan korumak için çok az şey yapılmaktadır. Çocukları şiddetten korumanın, toplumları şiddetten arındıracağı da düşünüldüğgunde, bu alanda yapılacak çalışmaların önemi yadsınamaz (Türkiye'de Çocuk İstismarı, 2010:10). Çocuklara karş1 işlenen istismar suçunun meydana gelmesinin pek çok çeşitli nedeni vardır. İstismar, çocukların küçük yaşlarda yaşadıkları ve maruz kaldıkları tüm kötü muameleler çocukta travma etkisi yapar ve ileriki yaşlarda duygusal ve davranışsal bozukluklara neden olur. Çocuk istismarı bir çeşit şiddet döngüsü halini almıştır. Çocuklarını istismar edenler aynı zamanda kendileri çocukluklarında istismara uğramış kişilerdir. Bugünün çocuk istismarının mağdurları yarının çocuk istismarcıları olmaktadır. Çocuk istismarıly mücadele toplumun tamamı ve tüm kurumlar tarafından ortak çabalarla yürütülmelidir. Çevreden, aileden ve çocuktan kaynaklanan nedenlerin birleşimi sonunda çocuk istismarının gerçekleștiği düşünüldüğ̈̈nde, çocuk istismarını meydana getiren bu çevresel ve kişisel faktörler ile aynı anda mücadele edilmelidir. Çocuk istismarı ile mücadele edebilmek için etkin kamu politikalarıyla geliştirilmelidir. Etkin kamu politikaları ve toplumsal farkındalık ile şiddetin nesilden nesile aktarılmasını sağlayan şiddet döngüsünün kırılması, çocukların istismardan korunmaları ve ebeveynlerin istismardan vazgeçirilmeleri gerekmektedir.

\section{Kaynaklar}

American Professional Society on the Abuse of Children, (APSAC, 1995), Guidelines for the Psychosocial Evaluation of Suspected Psychological Maltreatment in Children and Adolescents. Chicago, IL: APSAC.

Claussen, A. ve Crittenden, P, (1991), Physical and psychological maltreatment: relations among types of maltreatment. Child Abuse and Neglect, 15, ss. 5-18.

Crittenden, Patricia, (1999), Child neglect: causes and contributors. In H. Dubowitz (der.), Neglected Children: Research, practice and policy. Thousand Oaks: Sage, ss. 47-68.

Erickson, Martha. ve Egeland, Bayron, (2002), Child neglect. In J. Myers, L. Berliner, J. Briere, C. T. Hendrix, C. Jenny \& T. Reid (Der.), The APS AC handbook on child maltreatment, Thousand Oaks, CA: Sage. ss. 3-20.

Güneş, Adem, (2012), Cocuk Ë̆itiminde Poziitif İletişim. Nesil Yayınları. İstanbul

Güneş, Adem, (2014), Güvenli Bağlanma Timaş Yayınları. İstanbul

Hart, Stuard., Brassard, Marla. ve Karlson, Henry, (1996), Psychological maltreatment. In J. Briere ve ark. (Der.), The APS AC Handbook on Child Maltreatment.Thousand Oaks: Sage, ss. 72-89.

Hart, Stuard., Brassard, Marla., Binggeli, Nelson. ve Davidson, Howard, (2002), Psychological maltreatment. In J. Myers, L. Berliner, J. Briere, C.T. Hendrix, J. Carole and T. Reid(Der), 
Özgentürk, İ. (2014). Çocuk istisman1 ve ihmal. International Journal of Human Sciences, 11(2), 265-278. doi: $\underline{10.14687 / \text { ijhs.v11i1.2943 }}$

The APS AC Handbook on Maltreatment, Thousand Oaks: Sage, ss. 79-103.

Horozgil, Denizhan, (2011), Çocukların Cinsel İstismarı Suçunun Basit Şekli. TBB Dergisi (93). ss. $108-146$

Howe, David, (2005), Child Abuse and Neglect. Palgrave Macmillan. New York.

Iwaniec, Dorota, (2006), The Emotionally Abused and Neglected Child. John Wiley\&Sons, Ltd. England

Kara, Bülent., Biçer, Ümit., Gökalp, Ayşe.Sevim, (2004), “Çocuk İstismarı”, Çocuk Saglıg1

Ve Hastalıklar1 Dergisi, 47: ss.140-151.

Knutson, John, (1995), Psychological characteristics of maltreated children: putative risk factors and consequences. Psychology 46, ss. 401-31.

Polat, O, (2000), "Çocukta Cinsel İstismar", Adli Tip, Der Yayınları, ss. 207-231

Polonko, Karen, (2006), Exploring Assumptions about Child Neglecting Relation to the Broader Field of Child Maltreatment. JHHS Winter, ss. 260-282

Miller-Perrin, C. ve Perrin, R, (1999), Child Maltreatment: An introduction. Thousand Oaks: Sage.

Rapp-Paglicca, Lisa and Leober, Polly, (2007), "Child Abuse and Juvenile Delinquency", Nicky

Ali Jackson (Der.), Encyclopedia of Domestic Violence, New York:Routledge, ss.124-131

Reder, Peter, ve Duncan, Slyvia, (2000), Abuse then and now. In P. Peder, M. McClure and A.

Jolley (Der), Family Matters: Interfaces between child and adult mental health. London: Routledge, ss. 38-54.

Schwartz, Beth ve McCauley, Micheller, (2007), “Child Abuse: A Global Perpective" ”, Nicky Ali Jackson(Der.), Encyclopedia of Domestic Violence, New York: Routledge, ss.119-123.

Orhon, Filiz Şimşek., Ulukol, Betül.ve Bingöller, (2004), "Çocuk İstismarına Disiplin Penceresinden Bakıs", Adli Bilimler Dergisi, (3),1: ss.47-52.

The Child Abuse Prevention and Treatment Act, (2010), CAPTA, Section I, Definations.

Traşçı, Yaşar ve Gören, Süleyman, (2007), Çocuk İstismarı ve İhmal. Dicle Tıp Derğisi. (34), 1:ss.70-74

Turhan, Ebru., Sangün, Ö. ve İnandı, Tacettin, (2002), Birinci Basamakta Çocuk İstismarı ve Önlenmesi. Sürekli Tap Egitimi Dergisi. (15), 9: ss.153-157

Türkiye'de Çocuk İstismarı, (2010), Türkiye'de Çocuk İstismarı ve Aile İçi Şiddet Araştırması Özet Rapor. Başbakanlık Sosyal Hizmetler ve Çocuk Esirgeme Kurumu. Ankara

Ovayolu, Nimet., Uçan, Özlem. Ve Serindağ, Selver, (2007), Çocuklarda Cinsel İstismar ve Etkileri. Furat Sağllk Hizmetleri Dergisi, (2), 4: ss.13-22

Özgentürk, İlyas, Karğın, Vedat., Baltac1, Halil, (2012), Aile İçi Şiddet ve Şiddetin Nesilden Nesile İletilmesi. Polis Bilimleri Dergisi, (14),4: ss.

Yılmaz, Gonca., İşiten, Nuket., Ertan, Ülker ve Öner, Ayşe, (2003), 'Bir Çocuk İstismarı Vakası", Çocuk Saglıg1 ve Hastalıkları Dergisi, 46: ss.295-298

Zeren, Cem., Yengil, Erhan., Çelikel, Adnan., Arır, Ayşegül. Arslan, Mustafa, (2012), Üniversite Öğrencilerinde Çocukluk Çağı İstismarı Sıklığı. Dicle Tıp Dergisi. (39),4: ss.536-441

Zoroglu, Salih., Tüzün, Ümran., Sar, Vedat., Öztürk, Mucahit., Eröcal Kora, Meltem., Alyanak, Behiye, (2001), "Çocukluk Dönemi istismar ve ihmalinin Olası Sonuçları", Anadolu Psikiyatri Derg, (2),2: ss. 69-78.

WHO (2014). Dünya Sağlık Örgütü. http://www.who.int/violence injury prevention/ iolence/ child/en/

\section{Extended English Abstract}

Children's physical, emotional and sexual abuse and neglect are widespread social and health problem across societies. Societies and governments viewed child abuse in the family as a private problem. Child abuse was mainly ignored, or the importance was reduced because it was thought to be a private matter for families. But later it was accepted that it was not problem of the individuals 

$\underline{10.14687 / \text { ijhs.v11i1.2943 }}$

but all sociaties. They have considerable many physical and psychological health consequences for victims and suspects. Child abuse covers all kinds of attitudes and neglects that affect and limit children physical and emotional development by the parents or child careers. The physical abuse of children by their parents is a very widespread human rights issue. The term physical child abuse includes a wide range of harsh, punitive, controlling and aggressive behaviors by the parents. Many parents attempt to control their unruly child with highly primitive and brutal techniques. Abused parents justify applying these techniques to discipline the wayward child. A more generic term "psychological maltreatment" covers emotional abuse, rejection and neglect. Emotional abuse is defined as: hostile or indifferent behavior which damages a child's self-esteem, degrades a sense of achievement, diminishes a sense of belonging, prevents health and vigorous development, and takes away a child's well-being. The outcome of failing to develop skill at managing the psychological consequences of emotional abuse and neglect which the authorities often fail to recognize increases with age not because of their early occurrence but due to accumulation of such events until a critical point is reached where it is recognized by a school teacher, neighbor or health worker. Sociologist and psychologist have always been researching the relationship between early life experiences and human growth and behavior. They believe that early life experiences have effects on the human's physical and emotional development. Psychologist consider role of genes, nature, nurture and environment for the shaping human personality. As an early life experience child abuse affects the children's emotional and physical development negatively. Many psychologists believe that there is a direct relationship between mental disorders and psychological distress of the adults. A child whose emotional development is disturbed lives with very serious psychological and communication problems as well as decrease of life quality. Abuse and neglect can adversely affect both the physical and mental health and development of children. When the young child fails to explore and understand their emotions, this can damage their psychological development. Compared with other children, emotionally abused children are more likely to feel scared, sad, anxious and distressed. They show oppositional and anti-social behaviors. If they attend to school, they generally fail. In situations of extreme emotional fear and stress, children can show poor development and a range of stress related disorders. Extraordinary continuing stress such as chronic stress can affect children's development and physiological health. Child abuse can be a learned and passed through cognitive behavior. It is known that the perpetrators of child abuse are also victims of child abuse in their own childhoods. Parents who maltreat their children were often subject to an emotionally brutal childhood themselves. Child abuse can be one kind of cycle of violence. Child maltreatment is one early learning experience that can create trauma and emotional maladjustment in adulthood. Today's victims of child abuse have a tendency to become the perpetrators of tomorrow's child of abuse. Today's victims of child abuse will become tomorrow's abusers if this cycle of violence is ignored. Even though child abuse is very prevalent and affects millions of children and adults in the world, very little can be done to protect children from this brutal threat. Several factors contribute to the generation of child abuse and neglect and these early life experiences might affect the child's physical and emotional development. Child abuse is one early learning experience that can create trauma and emotional maladjustment in adulthood. Often, abusive parents were also victims of child maltreatment in their childhood. Child abuse can be prevented by the collective efforts of the whole community. Establishing a collective consciousness about the harms of the child abuse can become the initial step of fighting against child abuse. The considerable success can be reached when effective public policies, which attribute to collective consciousness addressing different fractions of the society are established. Professionally coordinated affective intervention policies and early child protection programs are needed to cope with this issue of child maltreatment. 